\title{
Hydroponic systems and water management in aquaponics: $A$ review
}

\author{
Carmelo Maucieri, ${ }^{1,2}$ Carlo Nicoletto, ${ }^{1}$ Ranka Junge, ${ }^{2}$ Zala Schmautz, ${ }^{2}$ Paolo Sambo, ${ }^{1}$ \\ Maurizio Borin ${ }^{1}$ \\ ${ }^{1}$ Department of Agronomy, Food, Natural Resources, Animals and Environment, University of Padova, \\ Legnaro (PD), Italy; ${ }^{2}$ Institute of Natural Resource Sciences, Centre Ecological Engineering, Zurich \\ University of Applied Sciences, Wädenswil, Switzerland
}

\begin{abstract}
Aquaponics (AP), the integrated multi-trophic fish and plants production in quasi-closed recirculating system, is one of the newest sustainable food production systems. The hydroponic component of the AP directly influences water quality (in turn influencing fish growth and health), and water consumption (through evapotranspiration) of the entire system. In order to assess the role of the design and the management of the hydroponic component on the overall performance, and water consumption of the aquaponics, 122 papers published from 1979 to 2017 were reviewed. Although no unequivocal results were found, the nutrient film technique appears in several aspects less efficient than medium-based or floating raft hydroponics. The best system performance in terms of fish and plant growth, and the highest nutrient removal from water was achieved at water flow between $0.8 \mathrm{~L}$ $\mathrm{min}^{-1}$ and $8.0 \mathrm{~L} \mathrm{~min}^{-1}$. Data on water consumption of aquaponics
\end{abstract}

Correspondence: Carmelo Maucieri, Department of Agronomy, Food, Natural Resources, Animals and Environment (DAFNAE), University of Padova, Agripolis Campus, Viale dell’Università 16, 35020 Legnaro (PD), Italy. E-mail: carmelo.maucieri@unipd.it

Key words: Water consumption; nutrient film technique; floating raft; medium-filled grow beds

Acknowledgments: Project Acquaponica: nuovi sistemi integrati per un'agricoltura sostenibile - BIRD 2017 - Department of Agronomy, Food, Natural resources, Animals and Environment.

The work of Carmelo Maucieri was supported by Cost Action FA1305 The EU Aquaponics Hub; Realising Sustainable Integrated Fish and Vegetable Production for the EU grant COSTSTSM-ECOST-STSMFA1305-011016-080268 and by a Department of Agronomy, Food, Natural resources, Animals and Environment research grant Aquaponic - Sustainable management of aquaculture effluent as an unconventional source for irrigation and fertilisation of crops.

See online Appendix for additional Tables.

Received for publication: 5 May 2017.

Revision received: 15 June 2017.

Accepted for publication: 17 June 2017

CCopyright C. Maucieri et al., 2018

Licensee PAGEPress, Italy

Italian Journal of Agronomy 2018; 13:1012

doi:10.4081/ija.2017.1012

This article is distributed under the terms of the Creative Commons Attribution Noncommercial License (by-nc 4.0) which permits any noncommercial use, distribution, and reproduction in any medium, provided the original author(s) and source are credited. are scarce, and no correlation between the ratio of hydroponic unit surface/fish tank volume and the system water loss was found. However, daily water loss was positively correlated with the hydroponic surface/fish tank volume ratio if the same experimental conditions and/or systems were compared. The plant species grown in hydroponics influenced the daily water loss in aquaponics, whereas no effect was exerted by the water flow (reciprocating flood/drain cycle or constant flow) or type (medium-based, floating or nutrient film technique) of hydroponics.

\section{Introduction}

Aquaponics (AP), the combination of hydroponics and recirculating aquaculture (Rakocy et al., 2003) is a promising solution for the negative environmental impacts typically associated with intensive fish and crop production. In these integrated systems, nutrients that are excreted by the fish or generated by microbial activity (Munguia-Fragozo et al., 2015; Zou et al., 2016a) are absorbed by hydroponically cultured plants, thus treating the water before it is recycled to the fish tank (Endut et al., 2009; Tyson et al., 2011; Nichols and Savidov, 2012; Medina et al., 2016; Nuwansi et al., 2016). AP has received considerable attention due to its capability to sustain water quality, minimise fresh water consumption, and provide a marketable vegetable crop (McMurtry et al., 1997a, 1997b; Adler et al., 2000a; Lennard and Leonard, 2005; Graber and Junge, 2009; Danaher et al., 2011, 2013; Pantanella et al., 2011, 2015; Espinosa Moya et al., 2016; Shete et al., 2016). Nevertheless few microbial studies have been conducted to determine food safety status (Elumalai et al., 2017) suggesting that further research is needed to evaluate this aspect.

In the AP, the water quality required for fish production is maintained through biofilter and/or hydroponic section where: i) plants absorb dissolved fish wastes and products of microbial activity (McMurtry et al., 1993; Danaher et al., 2013; Silva et al., 2015; Goddek et al., 2016; Andriani et al., 2017); ii) several substances are removed through gas volatilisation $\left(\mathrm{CO}_{2}, \mathrm{CH}_{4}, \mathrm{~N}_{2}\right.$, $\mathrm{N}_{2} \mathrm{O}, \mathrm{NH}_{3}$, etc.) by the same processes as in conœstructed wetlands (Mander et al., 2014; Maucieri et al., 2017).

Due to its integrative character and multiple application scenarios from high-tech to low-tech, AP is an atypical and complex food production technology (König et al., 2016). As reviewed in Goddek et al. (2015), AP can be considered a sustainable agricultural production system and, in this respect, Lehman et al. (1993) define sustainable agriculture as agricultural practices which do not undermine our future capacity to engage in agriculture. Furthermore, Francis et al. (2003) report that production process inefficiencies can be reduced designing systems that close nutrient cycles, which is one of the main aspects of aquaponics (Goddek et 
al., 2015). The essential components of an aquaponic system are the fish-rearing tank, the settler, the biofilter and the hydroponic unit (Rakocy et al., 2012). As AP is a recirculation system, each component influences the entire process. The hydroponic component directly influences water quality, which is essential for fish rearing (Yildiz et al., 2017). It is also the main source of water loss by plant evapotranspiration. Because the design and operation of the hydroponic system influences the sustainability of the entire process, either directly in terms of water consumption and/or indirectly in terms of system management costs, particular attention should be paid to it. In order to contribute to the discussion on the importance of the hydroponic unit, we reviewed 122 papers published from 1979 to 2017 to summarise the effects of the hydroponic system type, and of the water flow on aquaponic systems performance and water consumption.

\section{Hydroponic systems}

Current hydroponic cultivation systems can be classified in relation to the method of nutrient solution supply to the plant roots (Hussain et al., 2014a). They can be also classified in two major groups: i) cultivation systems without substrate that include the nutrient film technique (NFT) (Cooper, 1979) and different types of floating raft systems; ii) medium based systems, where a certain volume of substrate ensures roots anchorage, and acts as substrate for microorganisms' attachment and water-nutritional flywheel (Figure 1). These last systems can be further distinguished on the basis of substrate used: organic, inorganic and synthetic (Enzo et al., 2001).

The choice of hydroponic type for an AP system may be based on the independent advantages conferred by any particular hydroponic component (Lennard and Leonard, 2006) or on life cycle assessment impact (Forchino et al., 2017). All the methods represented in Figure 1 can be integrated in an aquaponic system (Pattillo, 2017). However, choice influences the design of the entire system. For example, the need to install a separate biofilter depends on the hydroponic system type. In media-based hydroponic systems, the used medium usually provides enough surface for bacteria growth and filtration although mechanical filtration between fish and hydroponic components can be useful to maximise biofiltration performance. Conversely, NFT channels do not provide enough surface for bacteria growth and additional biofilters have to be installed (Nelson, 2008). An overview of hydroponic systems implemented in aquaponics studies from 1993 to 2017 is provided in Appendix. Most of these publications refer to a single hydroponic system and the most frequently used systems were the medium-filled growth beds followed by floating rafts (Figure 2). Only one species was cultivated in the majority of experiments (Figure 3). The medium-based hydroponics is also the system where the highest number of species has been tested, followed by floating rafts and NFT; lettuce (Lactuca sativa), water spinach (Ipomea aquatica), and tomato (Lycopersicum esculentum) were the most frequently used species (Figure 4).

Only $9 \%$ of the reviewed publications compared different types of hydroponic systems (Figure 2). Lennard and Leonard (2006) evaluated the effect of hydroponic system type (gravel bed, floating or NFT) on nutrient stripping, plant yields and fish growth in a 21-day experiment with Murray cod (Maccullochella peelii peelii) and lettuce (Lactuca sativa). They found the highest production in the gravel bed $\left(5.05 \mathrm{~kg} \mathrm{~m}^{-2}\right)$, followed by floating rafts $\left(4.47 \mathrm{~kg} \mathrm{~m}^{-2}\right)$ and NFT $\left(4.13 \mathrm{~kg} \mathrm{~m}^{-2}\right)$ and no effect of hydroponic

\section{A - FLOATING SYSTEM}

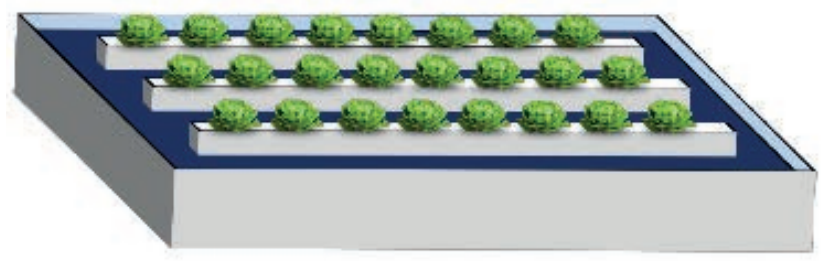

B- MEDIUM BASED

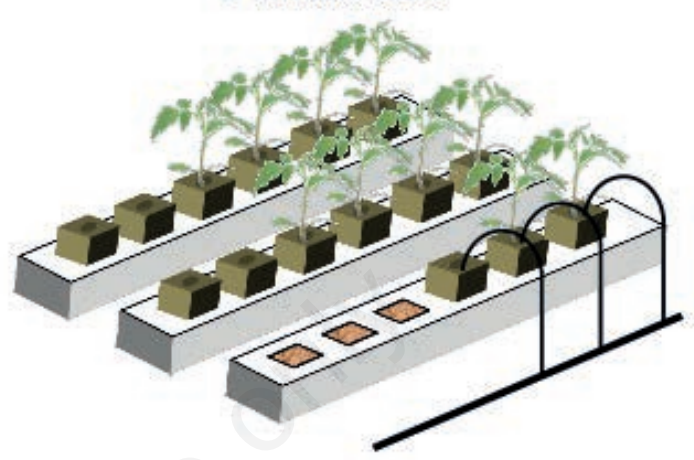

C- NUTRIENT FILM TECHNIQUE

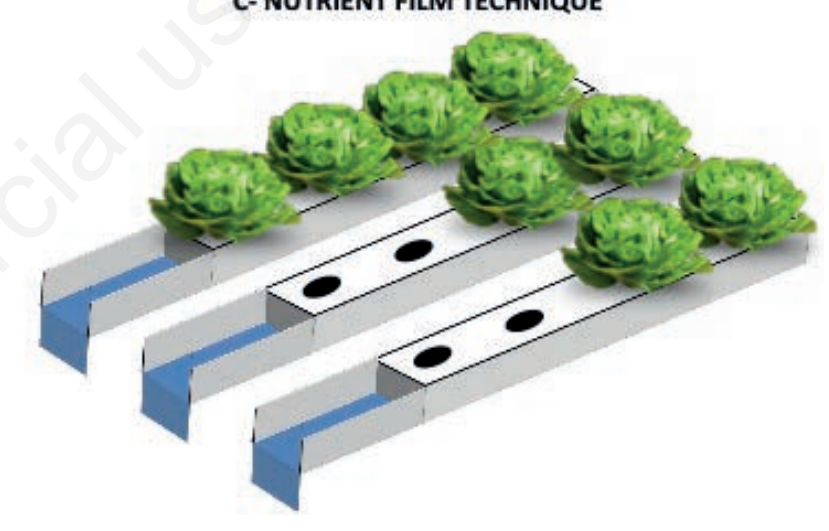

Figure 1. Schematic configuration of the most frequently used hydroponic cultivation systems.

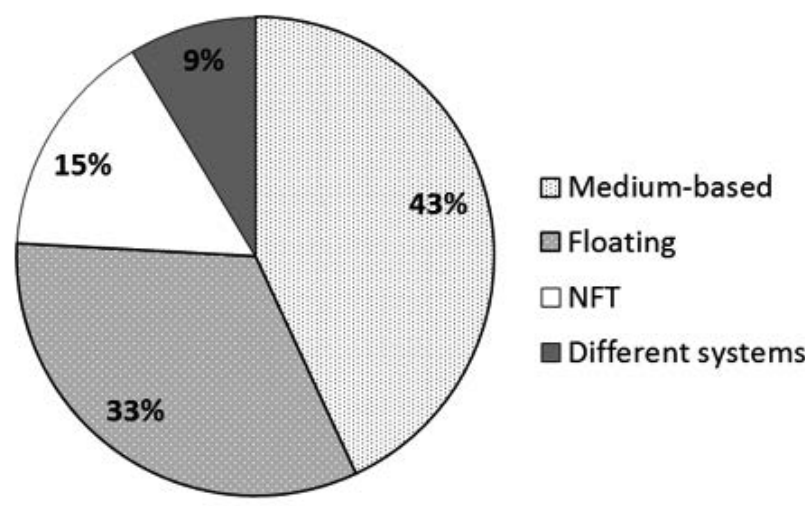

Figure 2. Percentage of papers for each type of hydroponics implemented in aquaponic systems (Total number of papers: 58 ). 
system on fish growth. Phosphate concentration in the water was not influenced by the hydroponics type (average value $3.6 \mathrm{mg} \mathrm{L}^{-1}$ ), while the nitrate concentration was significantly higher in the NFT $\left(15.7 \mathrm{mg} \mathrm{L}^{-1}\right)$ than in the other two systems $\left(3.6 \mathrm{mg} \mathrm{L}^{-1}\right)$ with a lower nitrate-N removal efficiency in the NFT. Schmautz et al. (2016) compared tomato yield, morphological characteristics, biochemical characteristics and overall plant vitality in an AP using NFT, floating rafts, and drip irrigation with coconut fibre as substrate. Although the fruit quality was similar in all three systems, the tomato yield in the drip irrigation system was higher $(18.7 \mathrm{~kg}$ $\left.\mathrm{m}^{-2}\right)$ than in NFT $\left(17.5 \mathrm{~kg} \mathrm{~m}^{-2}\right)$ and floating rafts $\left(17.4 \mathrm{~kg} \mathrm{~m}^{-2}\right)$. Goda et al. (2015) compared NFT with floating raft systems using different fish and plant species, showing that both systems were profitable. Moldovan and Bala (2015) compared medium-based and floating hydroponic systems using water from a pool populated by Cariassus auratus. They concluded that the floating system is cheaper in construction and maintenance, whereas the mediumbased system provides plants with added stability and can thus support larger plants.

Lennard and Leonard (2006) found the NFT system to be less efficient in terms of nutrient removal and lettuce yield than the medium-based or floating raft system Schmautz et al. (2016) obtained significantly lower tomato production in NFT than floating raft system but not than medium-based system. The lower nutrient removal capacity may be due to the restricted contact between the roots and the water. Plants grown in medium-based and floating hydroponic systems have their entire roots in contact with the water, providing them with more surface area to assimilate nitrate. In contrast, plant phosphate assimilation is not simply dependent upon the root area available to the water column (Lennard and Leonard, 2006) but also by water temperature (Adams, 1993) and pH (Raviv and Leith, 2008).

Nevertheless, NFT appears be an appropriate technology for aquaponics, based on capital cost and ease of use (Lennard and Leonard, 2006; Goda et al., 2015). Probably due to these reasons, some AP companies (i.e., UrbanFarmers, www.urbanfarmers.com) are using NFT channels for hydroponic section in commercial scale AP. Comparative studies are also rare, because researchers have more often used growth beds, whereas commercial operators more often use NFT. In view of these remarks, it would be desirable to conduct future research in commercial AP setting, in order to evaluate the performance of different soilless systems under realistic conditions.

\section{Substrate types}

The most important requirement of a hydroponic growing medium is that it holds sufficient water and air to maintain optimum conditions for root and consequently plant growth (Hardgrave, 1995). Roosta and Afsharipoor (2012) evaluated the effect of different substrates (sole perlite, $75 \%$ perlite $+25 \%$ cocopeat, $50 \%$ perlite $+50 \%$ cocopeat, $25 \%$ perlite $+75 \%$ cocopeat, and sole cocopeat) on growth and development of strawberry plants in aquaponics with Grass carp (Ctenopharyngodon idella) and Silver carp (Hypophthalmichthys molitrix), concluding that the substrates with the higher percentage of perlite performed better. They also observed that: i) the lowest dry root weight was obtained from sole perlite and sole cocopeat; ii) the cocopeat $(75: 25)$ produced the highest number of runners; iii) SPAD index in young leaves decreased as the ratio of perlite to cocopeat decreased; iv) maximal quantum yield of PS II photochemistry (Fv/Fm) decreased with the increase of cocopeat to perlite ratio; v) sole perlite carried the highest number of fruits.

Buhmann et al. (2015) evaluated the effects of hydroponic sys- tem (medium-based $v s$ floating), and substrate type (expanded clay vs sand) on Tripolium pannonicum (Jacq.) Dobrocz. using artificial seawater. Neither the hydroponic system nor the substrate influenced the fresh biomass weight or $\mathrm{N}$ uptake, whereas expanded clay provided a significantly higher $(+54.1 \%)$ dry matter production than

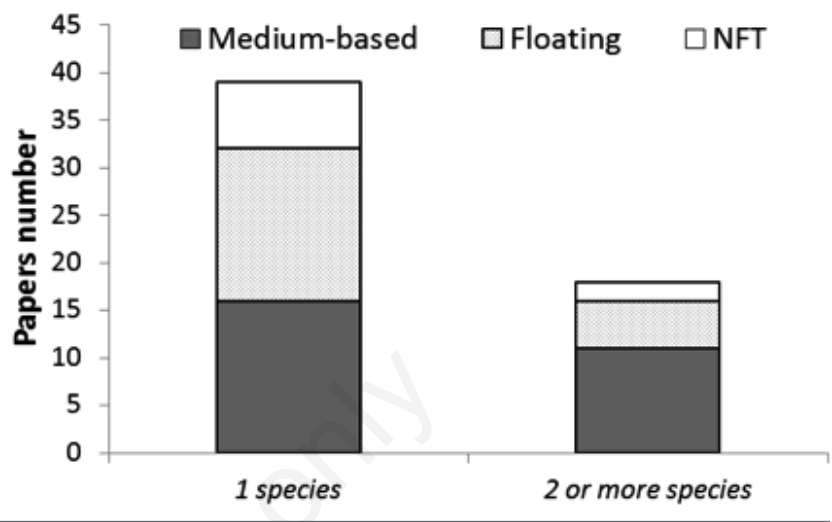

Figure 3. Number of papers that report results on one or more than one species and used hydroponic system.

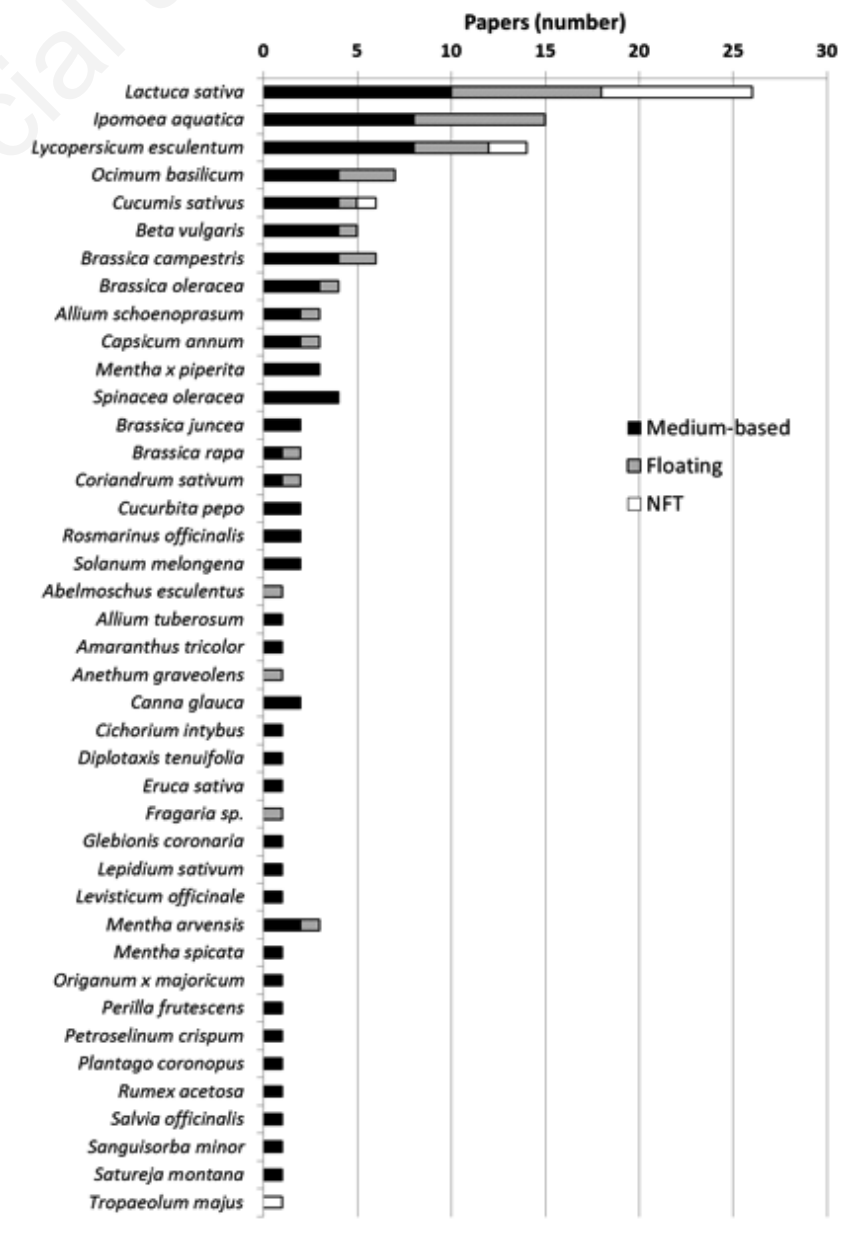

Figure 4. Plant species used in aquaponic systems with different hydroponic unit. 
sand (254 $\mathrm{g} \mathrm{m}^{-2}$ ). The phosphorus (P) uptake was approximately three times higher in the floating system, while there were no differences between substrates in the medium-based system. The substrate did not influence chlorophyll or carotenoids content, whereas plants grown in the sand bed showed a significantly higher content of these molecules than plants grown in the floating system.

Sikawa and Yakupitiyage (2010) used nutrient rich catfishpond water to produce lettuce and obtained higher head weight and yield in builders' grade sand $(0.10-0.25 \mathrm{~mm}$ in size $)$ than in gravel (2.5 $\mathrm{cm}$ in size). Geisenhoff et al. (2016) compared the production of lettuce using two substrates in medium-based hydroponics (crushed stone vs flexible polyurethane foam) in an AP system with Nile tilapia (Oreochromis niloticus). They did not observe significant differences in lettuce productivity, with an average yield of $2.27 \mathrm{~kg} \mathrm{~m}^{-2}$. On the other hand, flexible polyurethane foam resulted in higher concentrations of macro- and micronutrients in the shoot, a higher production of fresh shoot mass per plant $(+10.8 \%)$ and more leaves $(+22.1 \%)$ compared to the substrate with crushed stone. They attributed these results to reduced posttransplanting stress and to the increased water retention time provided by the flexible polyurethane foam. In addition, we hypothesize that the higher production with flexible polyurethane foam could be traced to the physical characteristics of this material that unlike crushed stone facilitate the penetration of the roots (Hardgrave, 1995) and increase both the root water contact time and exchange surface. Our hypothesis is also supported by the results of Buhmann et al. (2015) who obtained higher production with a more porous substrate (expanded clay), and by Sikawa and Yakupitiyage (2010), and Roosta and Afsharipoor (2012) who obtained higher production in the substrates with higher water retention capacities.

Rafiee and Saad (2006) investigated the effects of natural zeolite as a growth medium for lettuce in AP with red tilapia (Oreochromis sp.). They compared an AP system without zeolite as a control with one using a small cotton bag containing $10 \mathrm{~g}$ zeolite as a bed medium for a lettuce seedling. The presence of the zeolite exerted no significant effect on fish growth, while the lettuce yield was significantly higher (approximately 5.5 times). Furthermore, zeolite reduced the concentrations of inorganic $\mathrm{N}(-36.5 \%)$ and $\mathrm{P}$ $(-17.9 \%)$ in the system water. Zeolites are characterised by high cation-exchange capabilities, and are thus able to adsorb ammonium-N (Nguyen and Tanner, 1998; Wang and Peng, 2010; Borin et al., 2013; Markou et al., 2014). In addition, iron- and aluminiumbased crystalline and amorphous phases can become positively charged and, through a ligand exchange mechanism, their adsorption capabilities increase at neutral to acidic equilibrium $\mathrm{pH}$ values in comparison to alkaline conditions (Parfitt, 1979; Geelhoed et al., 1997). As a result, this zeolite was proposed as a $\mathrm{P}$ absorbent from wastewater (Wu et al., 2006). In AP systems, where ammonium $\left(\mathrm{NH}_{4}{ }^{+}\right)$ions are continuously produced by fish and bacteria, the zeolite can adsorb these ions on its surface, and it can also act as substrate for nitrifying bacteria. In addition, organic acid released through root exudates can change $\mathrm{pH}$ values near the zeolite surface, increasing its capability to absorb $\mathrm{P}$, an explanation that is supported by the results obtained by Rafiee and Saad (2006).

Crushed stones and river stones as substrate in AP with common carp (Cyprinus carpio) and mint (Mentha arvensis) have been compared by Shete et al. (2017) in terms of fish and plant growth, water quality, nutrient removal, and biofilter performance parameters concluding that the crushed stone medium was the most suitable. There is currently too little information available in the literature to draw conclusions about the effects of hydroponic substrate on AP. Nevertheless: i) zeolites appear as an interesting substrate for aquaponic systems for its capability to absorb nutrients and make these available for the roots; ii) there are some indications that the more porous substrate fosters plant nutrient uptake in AP, either by prolonging retention time with higher root-water contact time and/or providing attachment surface for microorganisms that solubilise nutrients.

\section{Water flow}

The water flow properties influence the contact time of the microorganisms and of roots with the water, which in turn influences both, the direct uptake of nutrients by plants, and the transformations by the microbial community (Effendi et al., 2015; Wahyuningsih et al., 2015).

\section{Continuous flow vs intermittent flow}

Intermittent cycles of flooding and draining in media filled beds provide uniform distribution of nutrients during the flood phase and improve aeration during the drain phase (McMurtry et al., 1997a). In continuous flow systems, high water retention time increases its contact time with roots and organisms, but it can lead to lower oxygenation rates and reduced nutrient availability. The complex removal mechanisms in the biofilter and the hydroponic component are similar to those of natural and constructed wetlands. In both, the removal of nutrients and/or pollutants is complex and depends on a variety of mechanisms, including sedimentation, filtration, precipitation, volatilisation, adsorption, plant uptake, and various microbial processes (Wießner et al., 2005; Vymazal, 2007; Wu et al., 2014; Barbera et al., 2015; Maucieri et al., 2014, 2016).

Lennard and Leonard (2005) compared a reciprocating flood/drain cycle (10 $\mathrm{min}$ flood every $70 \mathrm{~min}$ ) to a constant flow in a hydroponic gravel bed $\left(0.52 \mathrm{~m}^{2}\right)$ plated with lettuce during 21 day cycle. They obtained significantly higher lettuce yield (resulting in higher nitrate and phosphate assimilation), better $\mathrm{pH}$ buffering and higher dissolved oxygen concentrations in the constant flow.

In this context, species-specific responses to flow conditions should also be considered. Trang et al. (2010) studied the responses of Lactuca sativa, Ipomoea aquatica, Brassica rapa var. chinensis and Brassica rapa var. parachinensis to three root flooding conditions (drained, half-flooded and flooded) and observed that growth and performance of both Brassica varieties were best in the drained condition, while Lactuca sativa grew best in the halfflooded and Ipomea aquatica in the flooded.

\section{Effects of water recirculation period}

Several authors investigated the effects of different water recirculation periods on AP systems performance in terms of water quality, fish and vegetables production.

Sreejariya et al. (2016) tested three water recirculation regimes in a pilot AP system with hybrid tilapia (Oreochromis niloticus, $O$. mossambicus X $O$. hornorum X $O$. aureus) and lettuce (floating hydroponic): i) daytime recirculation, $11 \mathrm{~h}$; ii) night time recirculation, $13 \mathrm{~h}$; and iii) circadian recirculation, $24 \mathrm{~h}$. The duration of the recirculation did not significantly influence water quality, lettuce growth and quality, suggesting that recirculation can be reduced from $24 \mathrm{~h}$ to $11-13 \mathrm{~h}$.

Similarly, Shete et al. (2013a) investigated four recirculation periods $\left(4,8,12\right.$, and $\left.24 \mathrm{~h}^{\text {day }}{ }^{-1}\right)$ in a two-month trial, using a small aquaponic system with goldfish and spinach (Spinacea oler- 
acea). No significant differences in levels of total ammonium nitrogen (TAN), nitrite nitrogen $\left(\mathrm{NO}_{2}-\mathrm{N}\right)$, and nitrate nitrogen $\left(\mathrm{NO}_{3}-\mathrm{N}\right)$ were found among the four treatments. On the other hand, the fish growth was the highest under the $24 \mathrm{~h}$ recirculation and decreased with decreasing recirculation periods. There were no significant differences in spinach growth among the treatments; though the leaf chlorophyll content significantly decreased with decreased recirculation time, which could be caused by the lower nutrient availability. Even if the nutrient levels in the water were not significantly different, longer recirculation probably prevented the formation of micro-gradients around the roots, where nutrient depletion occurs on a very small spatial scale. They concluded that the optimal water circulation period was $12 \mathrm{~h} \mathrm{day}^{-1}$. Although the water $\mathrm{N}$ content detected in this study was lower than the reported optimal values for hydroponics (Pantanella et al., 2012; Bittsanszky et al., 2016; Delaide et al., 2016), this did not have a significant effect on crop yield.

In addition to water recirculation periods, water flow and hydraulic rate are major factors in AP systems performance. The optimisation of these parameters in AP is important considering that if low hydraulic load rate leads to oxygen deficiency and enables denitrification and $\mathrm{N}_{2}$ volatilisation, high hydraulic load rate reduces the contact time between water and roots (Wongkiew et al., 2017). A question arises as to whether it is more important the water recirculation frequency in the fish tanks or the water flow speed through the roots bringing fresh molecules. The comparison of different water flows in root zone and hydraulic rates of the system water are summarised on the Table 1.

Very low constant flow rates were studied by Khater et al. (2015) (Table 1) in AP system consisting of five fish tanks (each $40 \mathrm{~m}^{3}$ ) and three gullies (each $27 \mathrm{~m}^{2}$ ) covered with foam rafts to support tomato plants. As flow rates increased, the authors observed an increase in plant nutrient uptake for $\mathrm{N}(+87.8 \%), \mathrm{P}(+58.3 \%), \mathrm{K}$ $(+73.9 \%), \mathrm{Ca}(+89.1 \%)$ and $\mathrm{Mg}(+74.3 \%)$ coupled with increase in root and shoot length and biomass, fruit yield per plant and also water use efficiency (from 5.54 to $7.16 \mathrm{~kg} \mathrm{~m}^{-3}$ as flow rate increased from 0.067 to $0.1 \mathrm{~L} \mathrm{~min}^{-1}$ ). In a five-weeks trial, Endut et al. $(2009,2010)$ investigated different constant flow rates (Table 1) in an AP system with catfish (Clarius gariepinus; initial density = $\left.25 \mathrm{~kg} \mathrm{~m}^{-3}\right)$ and water spinach $\left(100\right.$ plants $\left.\mathrm{m}^{-2}\right)$ planted in gravelfilled grow beds. The highest fish $\left(45.7 \mathrm{~kg} \mathrm{~m}^{-3}\right)$, and plant $(17.9 \mathrm{~kg}$ bed ${ }^{-1}$ ) production and the highest $\mathrm{NO}_{3}-\mathrm{N}(64.9 \%)$, and TP $(52.8 \%)$ removal were observed at $1.6 \mathrm{~L} \mathrm{~min}^{-1}$, whereas the highest removal for $\mathrm{BOD}_{5}(65.5 \%)$, TSS (82.9\%), TAN (78.3\%) and $\mathrm{NO}_{2}-\mathrm{N}(89.5 \%)$ was found at $4.0 \mathrm{~L} \mathrm{~min}^{-1}$. Assuming that the optimum hydraulic loading rate is determined by a compromise between fish and plant production, $1.6 \mathrm{~L} \mathrm{~min}^{-1}$ can be considered the optimal water flow rate in this AP system (Endut et al., 2009, 2010). Similar flow rates, but with much higher complete fish tank water recirculation (Table 1) due to smaller fish tank volume were used by Nuwansi et al. (2016) in a 45-day experiment, which was conducted in a micro aquaponic system with a fish tank (70 L) with koi carp (Cyprinus carpio var. koi) and gold fish (Carassius auratus) and a gravel bed (100 L) planted with water spinach ( 28 plants $\mathrm{m}^{-2}$ ). Plant growth and nutrient removal increased as the flow rate decreased. The flow rate of $0.8 \mathrm{~L} \mathrm{~min}^{-1}$ yielded the highest water spinach biomass and the highest fish weight gain coupled with the lowest feed conversion rate (FCR).

Hussain et al. (2015) experimented with constant flow rates (Table 1), in a small aquaponic system with Cyprinus carpio var. koi (initial density $=1.4 \mathrm{~kg} \mathrm{~m}^{-3}$ ) and Beta vulgaris var. bengalensis (spinach) (28 plants $\mathrm{m}^{-2}$ ) for a period of 45 days. The hydroponic section was split into two gravel $(5-15 \mathrm{~mm})$ beds each of $0.51 \mathrm{~m}^{2}$.
Fish body weights were significantly higher at the two lower flow rates. The $1.5 \mathrm{~L} \mathrm{~min}^{-1}$ flow rate produced significantly higher plants $(24.3 \mathrm{~cm})$ than the other two treatments $(23.9 \mathrm{~cm})$, however the flow rate exerted no significant effect on yield (average $1.24 \mathrm{~kg}$ $\mathrm{m}^{-2}$ ). The water nutrient content at the end of the experiment was not significantly different between the treatments except for potassium, whose concentration was significantly lower $\left(14.3 \mathrm{mg} \mathrm{L}^{-1}\right)$ in the $1.5 \mathrm{~L} \mathrm{~min}^{-1}$ flow rate than the other two flow rates $(15.6 \mathrm{mg}$ $\left.\mathrm{L}^{-1}\right)$. Although flow rates showed similar performance in terms of fish growth, plant growth, and nutrient removal, the flow rate of $1.5 \mathrm{~L} \mathrm{~min}^{-1}$ seemed to be the most effective for spinach and koi carp growth.

Dediu et al. (2012) evaluated water quality, sturgeon (initial density $\left.=7.56 \mathrm{~kg} \mathrm{~m}^{-3}\right)$ and lettuce $\left(44\right.$ plants $\left.\mathrm{m}^{-2}\right)$ growth under two hydraulic regimes (Table 1). The 21-day trial was carried out in a micro $\operatorname{AP}\left(1.8 \mathrm{~m}^{3}\right)$ with a floating raft system $\left(0.55 \mathrm{~m}^{2}\right)$. The oxygen concentration in the water at the higher flow rate $(6.32 \mathrm{mg}$ $\left.\mathrm{L}^{-1}\right)$ was significantly higher than that at the lower one $(5.89 \mathrm{mg}$ $\left.\mathrm{L}^{-1}\right)$, whereas an opposite trend was found for TAN (0.47 and 0.43 mg L ${ }^{-1}$ with 8 and $16 \mathrm{~L} \mathrm{~m}^{-1}$, respectively). Water flow did not influence nitrite and nitrate concentrations. Increasing the water flow caused lower lettuce production and fish FCR and higher total fish weight gain and protein efficiency ratio (PER). Although Dediu et al. (2012) used a micro AP system, the data obtained were in line with bigger AP systems, indicating, as confirmed by Maucieri et al. (2018), that micro AP systems reliably mimic fullscale units.

In view of these results, and to maximise the performance of AP systems, a constant flow should be preferred to a reciprocating flood/drain cycle applied on an hourly level (e.g., $10 \mathrm{~min}$ flood every $70 \mathrm{~min}$ ). Instead, if the water flow in the system is performed on a daily basis, recirculation can be reduced from $24 \mathrm{~h}$ to between 11 and $13 \mathrm{~h}$, during the day or night. Halving the pump operation times has a positive influence on both economic and environmental considerations. Most of the papers examined suggest that from 2.3 to 18 fish tank water recirculations per day (Table 1) should be adopted to maximise system performance in terms of fish growth, plant growth and nutrients removal, but in many cases different water recirculation rates correspond to the same water flow (Endut et al., 2009, 2010; Nuwansi et al., 2016). Considering the above reported literature, the water flow speed through the roots bringing fresh molecules is of greatest importance, with better performance between $0.8 \mathrm{~L}$ $\mathrm{min}^{-1}$ and $8.0 \mathrm{~L} \mathrm{~min}^{-1}$ (Table 1). However, this conclusion results from very few studies carried out with different (oft too low) fish

Table 1. Tested water flows and fish tank water recirculations per day in different aquaponic systems.

\begin{tabular}{|c|c|c|}
\hline $\begin{array}{l}\text { Water flow } \\
{\left[\mathrm{L} \mathrm{min}^{-1}\right]}\end{array}$ & $\begin{array}{c}\text { Fish tank water recirculation } \\
\text { [number of recirculations } \\
\text { per day] }\end{array}$ & Reference \\
\hline $0.8-1.6-2.4-3.2-4$ & $1.2-2.3-3.5-4.6-5.8$ & Endut et al., 2009, 2010 \\
\hline $8-16$ & $43-86$ & Dediu et al., 2012 \\
\hline $1-1.5-3.2$ & $12-18-32.4$ & Hussain et al., 2015 \\
\hline $0.067-0.083-0.1$ & Cannot be calculated & Khater et al., 2015 \\
\hline $0.8-2.4-4$ & $16.5-49.4-82.3$ & Nuwansi et al., 2016 \\
\hline $4.2-8.3-16.7$ & $12-24-48$ & Shete et al., 2016* \\
\hline $0.35-1.4-2.8$ & $0.5-2-4$ & Diem et al., 2017 \\
\hline
\end{tabular}

*The study is not discussed because results are obtained in a system with a very low fish density (Cyprinus carpio; initial density $=90 \mathrm{~g} \mathrm{~m}^{-3}$ ) that determine low ions concentration. Italic values are the best solution for each paper. 
densities, different hydroponic systems and plant species. Therefore, more studies are needed to confirm this assumption.

\section{Water consumption}

Fish farming requires a huge input of good quality water and discharges low quality water into the environment (Sauthier et al., 1998; De Stefani et al., 2011). Therefore, both the reduction of water input and the treatment of aquaculture effluent equally are important because water is a limited resource and effluent nutrient discharge can contribute to environmental degradation (Adler et al., 2000b).

Water exchange is the most effective and widely employed method for maintaining good water quality in aquaculture farms (Masser et al., 1999). The exchange rate varies from as high as $250 \%$ per day for extensive aquaculture to between 2 and $10 \%$ per

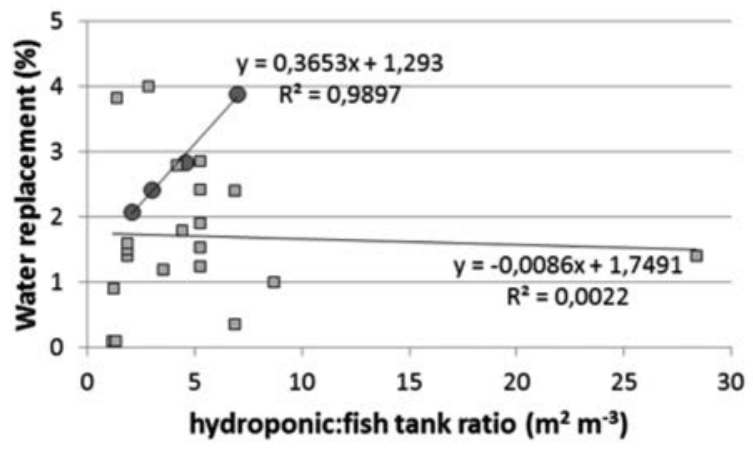

Figure 5. Hydroponic:fish tank ratio $\left(\mathrm{m}^{2} \mathrm{~m}^{-3}\right)$ and aquaponics system water replacement $(\%)$ correlation. Circular markers are referred at McMurtry et al. (1997b) paper, square markers are referred at all other reviewed papers except outlier water replacement values of Graber and Junge (2009).

Table 2. Aquaponic system characteristics and daily water consumption.

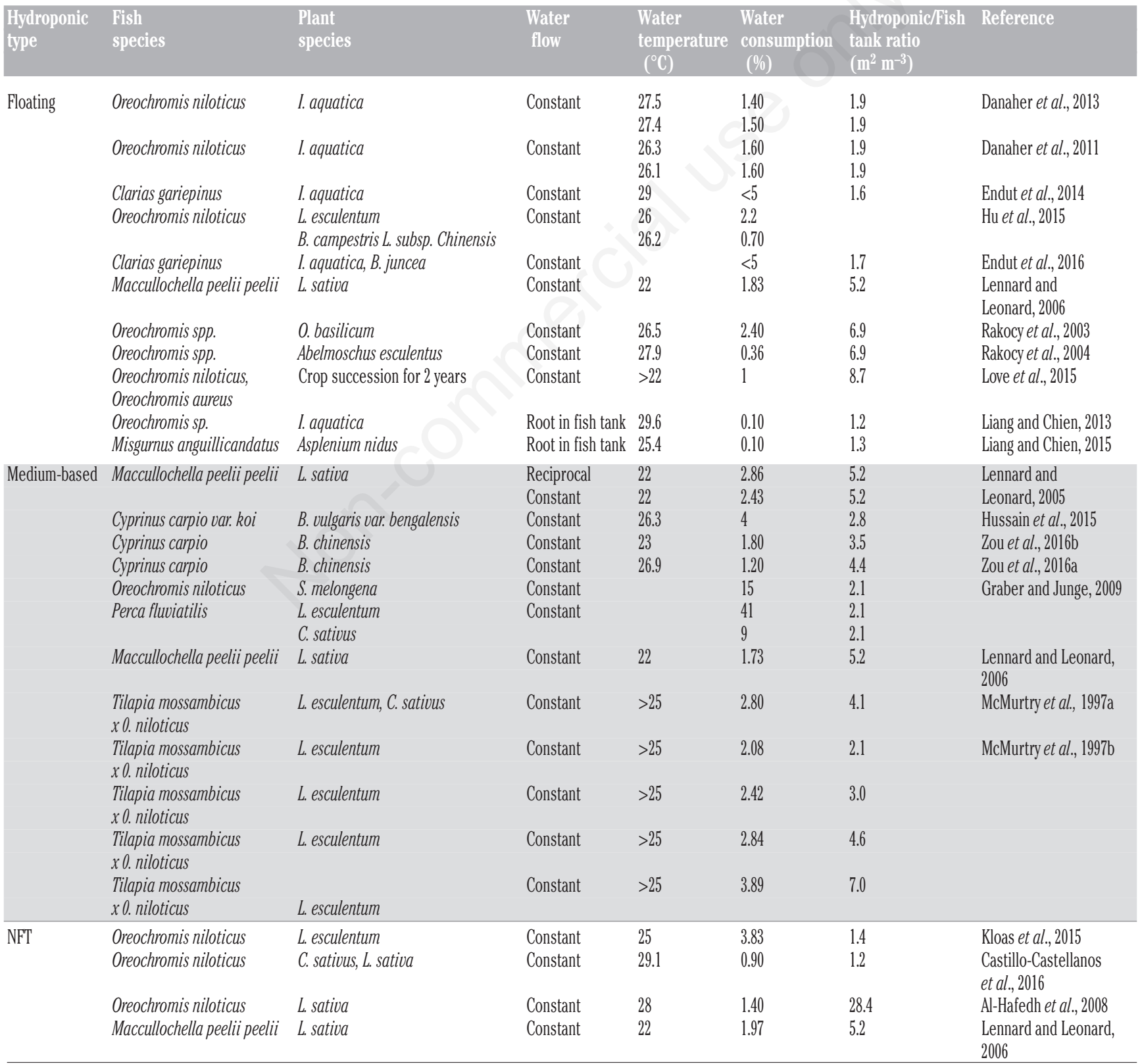


day for intensive aquaculture (Hu et al., 2015) and less than $1 \%$ for modern closed recirculating aquaculture systems (RAS) (Turcios and Papenbrock, 2014). Blidariu and Grozea (2011) define RAS as aquaculture systems that incorporate the treatment and reuse of water while replacing less than $10 \%$ of the total water volume per day. AP systems can be considered a type of RAS. Water is usually treated by mechanical and biological filtration, although additional water treatment elements (e.g., ultraviolet irradiation, ozonation) may be included (Hutchinson et al., 2004).

Daily water loss in AP systems is caused by fish sludge removal, evaporation, plant evapotranspiration, and fish splashing during feeding. These losses range from $0.05 \%$ (Goda et al., 2015) to $5 \%$ (Endut et al., 2014, 2016) of total water, although higher values $(9 \%-41 \%)$ have been found in particular conditions (Graber and Junge, 2009) (Table 2). The daily water loss is influenced among others (temperature, biofilter construction, greenhouse conditions) by the hydroponic surface/fish tank volume ratio. Increasing the hydroponic surface/fish tank volume ratio from 0.67 to 2.25 augmented the daily water replacement from $1.2 \%$ to $4.7 \%$ (McMurtry et al., 1997b). Lennard and Leonard (2005) measured an average daily consumption of $2.65 \%$ in an AP system with a medium-based hydroponic bed planted with $L$. sativa for 21 days and observed no influence of the management of the hydroponic section (reciprocating flood/drain cycle vs. constant flow) on the water. Also, the type of hydroponics (gravel, floating or NFT) had no influence on water loss (Lennard and Leonard, 2006) (Table 2).

Plant evapotranspiration is the most important factor that determines water loss. Graber and Junge (2009) observed a daily water loss of $9 \%, 15 \%$, and $41 \%$ with cucumber, aubergine and tomato, respectively. Hu et al. (2015) measured a daily water loss of $0.7 \%$, and $2.2 \%$ with pak choi, and tomato, respectively. The differences in the values for the tomato culture can be probably attributed to the higher hydroponic surface/fish tank volume ratio used by Graber and Junge (2009). No correlation was found between the hydroponic unit surface/fish tank volume ratio and the water loss across the different studies (Table 2, Figure 5). However, when the data were obtained in the same experiment (McMurtry et al., 1997b) the correlation was strongly positive (Figure 5); increasing the hydroponic unit surface/fish tank volume ratio of 3.4 times the water loss increased of 1.9 times. In view of this, although further research is needed to confirm the above reported findings, the daily water loss in the AP system is primarily influenced by the hydroponic surface/fish tank volume ratio and by the plant species used in the hydroponic section. There is no significant effect exerted by hydroponic section management (reciprocating flood/drain cycle or constant flow) or type (gravel, floating or NFT).

\section{Conclusions}

No unequivocal results have been found for hydroponic system types in AP in terms of yield and water quality. However, many companies are using NFT channels for hydroponic section in fullscale aquaponic systems, probably due to the easier management than other soilless systems. In view of this, further studies are desirable for a more comprehensive evaluation of hydroponic systems efficiency in the aquaponic systems. In terms of substrate characteristics in the medium-based technique, too little information is available in the literature to reliably identify the best performing substrate. However, the literature review suggests that more porous substrates should be preferred to maximise aquaponic systems performance.

To maximise the performance of AP systems, constant flow should be preferred to a reciprocating flood/drain cycle, if the systems are managed on a hourly basis (e.g., $10 \mathrm{~min}$ flood every 70 min). Instead, if the water flow in the system is managed on a daily basis (one continued recirculation for several hours each day), recirculation can be reduced from $24 \mathrm{~h}$ to $11-13 \mathrm{~h}$ during either the day or night. The halving of the pump operation time has a positive influence on both economic and environmental aspects. Most of the papers suggest that between 2.3 and 18 fish tank water recirculations per day with a water flow from $0.8 \mathrm{~L} \mathrm{~min}^{-1}\left(0.048 \mathrm{~m}^{3} \mathrm{~h}^{-1}\right)$ to $8.0 \mathrm{~L} \mathrm{~min}^{-1}\left(0.48 \mathrm{~m}^{3} \mathrm{~h}^{-1}\right)$ should maximise aquaponic system performance in terms of fish growth, plant growth and nutrients removal. Comparing information about water recirculation and water flow in the analysed literature, flow results more important for maximizing system performance although this arises from a few studies carried out with different fish species and density, different hydroponic systems and therefore further investigations are needed.

Daily water loss in the AP systems is primarily influenced by hydroponic surface/fish tank volume ratio and by the plant species used in the hydroponic section. No significant effect is exerted by hydroponic section management (reciprocating flood/drain cycle or constant flow) or type (gravel, floating or NFT).

\section{References}

Adams P, 1993. Nutrition of greenhouse vegetables in NFT and hydroponic systems. Acta Hortic. 361:245-7.

Adler PR, Harper JK, Wade EM, Takeda F, Summerfelt ST, 2000a. Economic analysis of an aquaponic system for the integrated production of rainbow trout and plants. Int. J. Recirc. Aquacult. 1:15-34.

Adler PR, Harper JK, Takeda F, Wade EM, Summerfelt ST, 2000b. Economic evaluation of hydroponics and other treatment options for phosphorus removal in aquaculture effluent. HortSci. 35:993-9.

Al-Hafedh YS, Alam A, Beltagi MS, 2008. Food production and water conservation in a recirculating aquaponic system in Saudi Arabia at different ratios of fish feed to plants. J. World Aquacult. Soc. 39:510-20.

Andriani Y, Dhahiyat Y, Zahidah IZ, 2017. The effect of stocking density ratio of fish on water plant productivity in aquaponics culture. Nus. Biosci. 9:31-5.

Barbera AC, Borin M, Cirelli GL, Toscano A, Maucieri C, 2015. Comparison of carbon balance in Mediterranean pilot constructed wetlands vegetated with different $\mathrm{C} 4$ plant species. Environ. Sci. Pollut. R. 22:2372-83.

Bittsanszky A, Uzinger N, Gyulai G, Mathis A, Junge R, Villarroel M, Kotzen B, Komives T, 2016. Nutrient supply of plants in aquaponic systems. Ecocycles 2:17-20.

Blidariu F, Grozea A, 2011. Increasing the economical efficiency and sustainability of indoor fish farming by means of aquaponics-review. Sci. P. Anim. Sci. Biotechnol. 44:1-8.

Blidariu F, Alexandru D, Adrian G, Isidora R, Dacian L, 2013. Evolution of nitrate level in green lettuce conventional grown under natural conditions and aquaponic system. Sci. P. Anim. Sci. Biotechnol. 46:244-50.

Borin M, Politeo M, De Stefani G, 2013. Performance of a hybrid constructed wetland treating piggery wastewater. Ecol. Eng. 51:229-36 
Buhmann AK, Waller U, Wecker B, Papenbrock J, 2015. Optimization of culturing conditions and selection of species for the use of halophytes as biofilter for nutrient-rich saline water. Agric. Water Manage. 149:102-14.

Buzby KM, Lin LS, 2014. Scaling aquaponic systems: Balancing plant uptake with fish output. Aquacult. Eng. 63:39-44.

Buzby KM, Waterland NL, Semmens KJ, Lin LS, 2016. Evaluating aquaponic crops in a freshwater flow-through fish culture system. Aquaculture 460:15-24.

Cani ACP, Azevedo RVD, Pereira RN, Oliveira MAD, Chaves MA, Braga LGT, 2013. Phytodepuration of the effluents in a closed system of fish production. Rev. Brasil. Saúde Prod. Animal 14:371-81.

Castillo-Castellanos D, Zavala-Leal I, Ruiz-Velazco JMJ, RadillaGarcía A, Nieto-Navarro JT, Romero-Bañuelos CA, GonzálezHernández J, 2016. Implementation of an experimental nutrient film technique-type aquaponic system. Aquacult. Int. 24:637-46.

Cooper A, 1979. The ABC of NFT. Nutrient film technique. Grower Books, London, UK.

da Silva Cerozi B, Fitzsimmons K, 2016. Use of Bacillus spp. to enhance phosphorus availability and serve as a plant growth promoter in aquaponics systems. Sci. Hortic. 211:277-82.

Danaher JJ, Shultz RC, Rakocy JE, Bailey DS, 2013. Alternative solids removal for warm water recirculating raft aquaponic systems. J. World Aquacult. Soc. 44:374-83.

Danaher JJ, Shultz RC, Rakocy JE, Bailey DS, 2011. Effect of a parabolic screen filter on water quality and production of Nile tilapia (Oreochromis niloticus) and water spinach (Ipomoea aquatica) in a recirculating raft aquaponic system. Int. J. Recirc. Aquac. 12:35-53.

Dediu L, Cristea V, Xiaoshuan Z, 2012. Waste production and valorization in an integrated aquaponic system with bester and lettuce. Afric. J. Biotechnol. 11:2349-58.

Delaide B, Goddek S, Gott J, Soyeurt H, Jijakli MH, 2016. Lettuce (Lactuca sativa L. var. Sucrine) growth performance in complemented aquaponic solution outperforms hydroponics. Water 8:467.

De Stefani G, Tocchetto D, Salvato M, Borin M, 2011. Performance of a floating treatment wetland for in-stream water amelioration in NE Italy. Hydrobiologia 674:157-67.

Diem TNT, Konnerup D, Brix H, 2017. Effects of recirculation rates on water quality and Oreochromis niloticus growth in aquaponic systems. Aquacult. Eng.78: 95-104.

Effendi H, Utomo BA, Darmawangsa GM, Sulaeman N, 2015. Combination of water spinach (Ipomea aquatica) and bacteria for freshwater cryfish red claw (Cherax quadricarinatus) culture wastewater treatment in aquaponic system. J. Adv. Biol. $6: 3$.

Elumalai SD, Shaw AM, Pattillo DA, Currey CJ, Rosentrater KA, Xie K, 2017. Influence of UV treatment on the food safety status of a model aquaponic system. Water 9:27.

Endut A, Jusoh A, Ali NA, 2014. Nitrogen budget and effluent nitrogen components in aquaponics recirculation system. Desalin. Water Treat. 52:744-52.

Endut A, Jusoh A, Ali N, Nik WW, Hassan A, 2010. A study on the optimal hydraulic loading rate and plant ratios in recirculation aquaponic system. Bioresour. Technol. 101:1511-7.

Endut A, Jusoh A, Ali N, Wan Nik WNS, Hassan A, 2009. Effect of flow rate on water quality parameters and plant growth of water spinach (Ipomoea aquatica) in an aquaponic recirculating system. Desalin. Water Treat. 5:19-28.

Endut A, Lananan F, Abdul Hamid SH, Jusoh A, Wan Nik WN,
2016. Balancing of nutrient uptake by water spinach (Ipomoea aquatica) and mustard green (Brassica juncea) with nutrient production by African catfish (Clarias gariepinus) in scaling aquaponic recirculation system. Desalin. Water Treat. 57:29531-40.

Endut A, Jusoh A, Ali N, Wan Nik WB, 2011. Nutrient removal from aquaculture wastewater by vegetable production in aquaponics recirculation system. Desalin. Water Treat. 32:42230 .

Enzo M, Gianquinto G, Lazzarin R, Pimpini F, Sambo P, 2001. Principi tecnico-agronomici della fertirrigazione e del fuori suolo. Tipografia-Garbin, Padova, Italy.

Espinosa Moya EA, Angel Sahagún CA, Mendoza Carrillo JM, Albertos Alpuche PJ, Álvarez-González CA, Martínez-Yáñez R, 2016. Herbaceous plants as part of biological filter for aquaponics system. Aquacult. Res. 47:1716-26.

Filep RM, Diaconescu Ş, Costache M, Stavrescu-Bedivan MM, Bădulescu L, Nicolae CG, 2016. Pilot aquaponic growing system of carp (Cyprinus Carpio) and basil (Ocimum Basilicum). Agric. Agric. Sci. Proc. 10:255-60.

Forchino AA, Lourguioui H, Brigolin D, Pastres R, 2017. Aquaponics and sustainability: The comparison of two different aquaponic techniques using the life cycle assessment (LCA). Aquacult. Eng. 77:80-8.

Francis C, Lieblein G, Gliessman S, Breland TA, Creamer N, Harwood R, 2003. Agroecology: the ecology of food systems. J. Sustain. Agr. 22:99-118.

Geelhoed JS, Hiemstra T, Van Riemsdijk WH, 1997. Phosphate and sulfate adsorption on goethite: single anion and competitive adsorption. Geochim. Cosmochim. Ac. 61:2389-96.

Geisenhoff LO, Jordan RA, Santos RC, Oliveira FCD, Gomes EP, 2016. Effect of different substrates in aquaponic lettuce production associated with intensive tilapia farming with water recirculation systems. Eng. Agr. 36:291-9.

Goda AMA, Essa MA, Hassaan MS, Sharawy Z, 2015. Bio Economic features for aquaponic systems in Egypt. Turk. J. Fish. Aquat. Sci. 15:525-32.

Goddek S, Delaide B, Mankasingh U, Ragnarsdottir KV, Jijakli H, Thorarinsdottir R, 2015. Challenges of sustainable and commercial aquaponics. Sustainability 7:4199-24.

Goddek S, Schmautz Z, Scott B, Delaide B, Keesman KJ, Wuertz S, Junge R, 2016. The effect of anaerobic and aerobic fish sludge supernatant on hydroponic lettuce. Agronomy 6:37.

Graber A, Junge R, 2009. Aquaponic systems: nutrient recycling from fish wastewater by vegetable production. Desalination 246:147-56.

Hardgrave M, 1995. An evaluation of polyurethane foam as a reusable substrate for hydroponic cucumber production. Acta Hortic. 401:201-8.

$\mathrm{Hu}$ Z, Lee JW, Chandran K, Kim S, Brotto AC, Khanal SK, 2015. Effect of plant species on nitrogen recovery in aquaponics. Bioresour. Technol. 188:92-8.

Hussain A, Iqbal K, Aziem S, Mahato P, Negi AK, 2014a. A review on the science of growing crops without soil (Soilless Culture)A novel alternative for growing crops. Int. J. Agric. Crop Sci. 7:833.

Hussain T, Verma AK, Tiwari VK, Prakash C, Rathore G, Shete AP, Nuwansi KKT, 2014b. Optimizing Koi Carp, Cyprinus carpio var. Koi (Linnaeus, 1758), Stocking density and nutrient recycling with spinach in an aquaponic system. J. World Aquacult. Soc. 45:652-61.

Hussain T, Verma AK, Tiwari VK, Prakash C, Rathore G, Shete AP, Saharan N, 2015. Effect of water flow rates on growth of 
Cyprinus carpio var. koi (Cyprinus carpio L., 1758) and spinach plant in aquaponic system. Aquacult. Int. 23:369-84.

Hutchinson W, Jeffrey M, O'sullivan D, Casement D, Clarke S, 2004. Recirculating aquaculture systems minimum standards for design, construction and management. Inland Aquaculture Association of South Australia, Inc., Kent Town.

Johnson GE, Buzby KM, Semmens KJ, Holaskova I, Waterland NL, 2017. Evaluation of lettuce between spring water, hydroponic and flow-through aquaponic systems. Int. J. Veg. Sci. 23:456-70.

Khater ESG, Bahnasawy AH, Shams AEHS, Hassaan MS, Hassan YA, 2015. Utilization of effluent fish farms in tomato cultivation. Ecol. Eng. 83:199-207.

Klemenčič AK, Bulc TG, 2015. The use of vertical constructed wetland and ultrasound in aquaponic systems. Environ. Sci. Pollut. Res. 22:1420-30.

Kloas W, Groß R, Baganz D, Graupner J, Monsees H, Schmidt U, et al., 2015. A new concept for aquaponic systems to improve sustainability, increase productivity, and reduce environmental impacts. Aquacult. Environ. Interact. 7:179-92.

König B, Junge R, Bittsanszky A, Villarroel M, Komives T, 2016. On the sustainability of aquaponics. Ecocycles 2:26-32.

Lam SS, Ma NL, Jusoh A, Ambak MA, 2014. A study on the optimal tank design and feed type to the growth of marble goby (Oxyeleotris marmorata Bleeker) and reduction of waste in a recirculating aquaponic system. Desalin. Water Treat. 52:104453.

Lam SS, Ma NL, Jusoh A, Ambak MA, 2015. Biological nutrient removal by recirculating aquaponic system: optimization of the dimension ratio between the hydroponic and rearing tank components. Int. Biodeter. Biodegr. 102:107-15.

Lehman H, Clark EA, Weise SF, 1993. Clarifying the definition of sustainable agriculture. J. Agr. Environ. Ethic. 6:127-43.

Lennard WA, Leonard BV, 2005. A comparison of reciprocating flow versus constant flow in an integrated, gravel bed, aquaponic test system. Aquacult. Int. 12:539-53.

Lennard WA, Leonard BV, 2006. A comparison of three different hydroponic sub-systems (gravel bed, floating and nutrient film technique) in an Aquaponic test system. Aquacult. Int. 14:539-50.

Liang JY, Chien YH, 2013. Effects of feeding frequency and photoperiod on water quality and crop production in a tilapiawater spinach raft aquaponics system. Int. Biodeter. Biodegr. 85:693-700.

Liang JY, Chien YH, 2015. Effects of photosynthetic photon flux density and photoperiod on water quality and crop production in a loach (Misgurnus anguillicandatus) - nest fern (Asplenium nidus) raft aquaponics system. Int. Biodeter. Biodegr. 102:214-22.

Love DC, Uhl MS, Genello L, 2015. Energy and water use of a small-scale raft aquaponics system in Baltimore, Maryland, United States. Aquacult. Eng. 68:19-27.

Markou G, Vandamme D, Muylaert K, 2014. Using natural zeolite for ammonia sorption from wastewater and as nitrogen releaser for the cultivation of Arthrospira platensis. Bioresour. Technol. 155:373-8.

Masser MP, Rakocy J, Losordo TM, 1999. Recirculating aquaculture tank production systems - management of recirculating systems. SRAC Publication, No. 452 USDA. Available from: https://srac.tamu.edu/index.cfm/event/getFactSheet/whichfactsheet/103/

Maucieri C, Borin M, Barbera AC, 2014. Role of C3 plant species on carbon dioxide and methane emissions in Mediterranean constructed wetland. Ital. J. Agron. 9:120-6.

Maucieri C, Mietto A, Barbera AC, Borin M, 2016. Treatment per- formance and greenhouse gas emission of a pilot hybrid constructed wetland system treating digestate liquid fraction. Ecol. Eng. 94:406-17.

Maucieri C, Barbera AC, Vymazal J, Borin M, 2017. A review on the main affecting factors of greenhouse gases emission in constructed wetlands. Agr. Forest Meteorol. 236:175-93.

Maucieri C, Forchino AA, Nicoletto C, Junge R, Pastres R, Sambo P, Borin M, 2018. Life cycle assessment of a micro aquaponic system built using recovered material and usable for education purposes. J. Clean. Prod. 172:3119-27.

McMurtry MR, Sanders DC, Cure JD, Hodson RG, 1997a. Effects of biofilter/culture tank volume ratios on productivity of a recirculating fish/vegetable co-culture system. J. Appl. Aquacult. 7:33-51.

McMurtry MR, Sanders DC, Cure JD, Hodson RG, Haning BC, St Amand EC, 1997b. Efficiency of water use of an integrated fish/vegetable co-culture system. J. World Aquacult. Soc. 28:420-8

McMurtry MR, Sanders DC, Patterson RP, Nash A, 1993. Yield of tomato irrigated with recirculating aquacultural water. J. Prod. Agric. 6:428-32.

Medina M, Jayachandran K, Bhat MG, Deoraj A, 2016. Assessing plant growth, water quality and economic effects from application of a plant-based aquafeed in a recirculating aquaponic system. Aquacult. Int. 24:415-27.

Moldovan IA, Bala M, 2015. Analysis of aquaponic organic hydroponics from the perspective of setting costs and of maintenance on substratum and floating shelves systems. J. Hortic. Forest. Biotechnol. 19:73-6.

Munguia-Fragozo P, Alatorre-Jacome O, Rico-Garcia E, TorresPacheco I, Cruz-Hernandez A, Ocampo-Velazquez RV, 2015. Perspective for aquaponic systems: "omic" technologies for microbial community analysis. BioMed Res. Int. Article ID 480386

Nelson RL, 2008. Aquaponic equipment the bio filter. Aquaponic J. 48:2.

Nguyen ML, Tanner CC, 1998. Ammonium removal from wastewaters using natural New Zealand zeolites. New Zeal. J. Agr. Res. 41:427-46.

Nichols MA, Savidov NA, 2012. Aquaponics: a nutrient and water efficient production system. Acta Hortic. 947:129-32.

Nozzi V, Parisi G, Di Crescenzo D, Giordano M, Carnevali O, 2016. Evaluation of Dicentrarchus labrax meats and the vegetable quality of Beta vulgaris var. cicla farmed in freshwater and saltwater aquaponic systems. Water 8:423.

Nuwansi KKT, Verma AK, Prakash C, Tiwari VK, Chandrakant MH, Shete AP, Prabhath GPWA, 2016. Effect of water flow rate on polyculture of koi carp (Cyprinus carpio var. koi) and goldfish (Carassius auratus) with water spinach (Ipomoea aquatica) in recirculating aquaponic system. Aquacult. Int. 24:385-93.

Palm HW, Bissa K, Knaus U, 2014b. Significant factors affecting the economic sustainability of closed aquaponic systems. Part II: fish and plant growth. AACL Bioflux 7:162-75.

Palm HW, Nievel M, Knaus U, 2015. Significant factors affecting the economic sustainability of closed aquaponic systems. Part III: Plant Units. AACL Bioflux 8:89-106.

Palm HW, Seidemann R, Wehofsky S, Knaus U, 2014a. Significant factors affecting the economic sustainability of closed aquaponic systems. Part I: system design, chemo-physical parameters and general aspects. AACL Bioflux 7:20-32.

Pantanella E, Cardarelli M, Colla G, Rea E, Marcucci A, 2012. Aquaponics vs. hydroponics: production and quality of lettuce 
crop. Acta Hortic. 927:887-93.

Pantanella E, Cardarelli M, Danieli PP, MacNiven A, Colla G, 2011. Integrated aquaculture - floating agriculture: is it a valid strategy to raise livelihood?. Acta Hortic. 921:79-86.

Pantanella E, Cardarelli M, Di Mattia E, Colla G, 2015. Aquaponics and food safety: effects of uv sterilization on total coliforms and lettuce production. Acta Hortic. 1062:71-6.

Parfitt RL, 1979. Anion adsorption by soils and soil materials. Adv. Agron. 30:1-50.

Pattillo, DA, 2017. An overview of aquaponic systems: hydroponic components. NCRAC Technical Bulletins \#123.

Rafiee G, Saad CR, 2006. The effect of natural zeolite (clinoptiolite) on aquaponic production of red tilapia (Oreochromis sp.) and lettuce (Lactuca sativa var. longifolia), and improvement of water quality. J. Agric. Sci. Technol. 8:313-22.

Rakocy JE, Bailey DS, Shultz RC, Thoman ES, 2004. Update on tilapia and vegetable production in the UVI aquaponic system. pp. 12-16 in New Dimensions on Farmed Tilapia: Proceedings of the Sixth International Symposium on Tilapia in Aquaculture, Held September.

Rakocy J, Masser M, Losordo T, 2012. Recirculating aquaculture tank production systems: aquaponics-integrating fish and plant culture. Southern Regional Aquaculture Center Publication\# 454.

Rakocy J, Shultz RC, Bailey DS, Thoman ES, 2003. Aquaponic production of tilapia and basil: comparing a batch and staggered cropping system. pp. 63-69 in South Pacific Soilless Culture Conference-SPSCC 648.

Raviv M, Leith JH, 2008. Soilless culture: theory and practice. Elsevier, Amsterdam, The Netherlands.

Roosta HR, Hamidpour M, 2011. Effects of foliar application of some macro-and micro-nutrients on tomato plants in aquaponic and hydroponic systems. Sci. Hortic. 129:396-402.

Roosta HR, Mohsenian Y, 2012. Effects of foliar spray of different Fe sources on pepper (Capsicum annum L.) plants in aquaponic system. Sci. Hortic. 146:182-91.

Roosta HR, Afsharipoor S, 2012. Effects of different cultivation media on vegetative growth, ecophysiological traits and nutrients concentration in strawberry under hydroponic and aquaponic cultivation systems. Adv. Environ. Biol. 6:543-55.

Sauthier N, Grasmick A, Blancheton JP, 1998. Biological denitrification applied to a marine closed aquaculture system. Water Res. 32:1932-8.

Sayara T, Amarneh B, Saleh T, Aslan K, Abuhanish R, Jawabreh A, 2016. Hydroponic and aquaponic systems for sustainable agriculture and environment. Int. J. Plant Sci. Ecol. 2:23-9.

Schmautz Z, Loeu F, Liebisch F, Graber A, Mathis A, Griessler Bulc T, Junge R, 2016. Tomato productivity and quality in aquaponics: comparison of three hydroponic methods. Water 8:533.

Seawright DE, Stickney RR, Walker RB, 1998. Nutrient dynamics in integrated aquaculture-hydroponics systems. Aquaculture 160:215-37.

Shete AP, Verma AK, Chadha NK, Prakash C, Peter RM, Ahmad I, Nuwansi KKT, 2016. Optimization of hydraulic loading rate in aquaponic system with Common carp (Cyprinus carpio) and Mint (Mentha arvensis). Aquacult. Eng. 72:53-7.

Shete AP, Verma AK, Tandel RS, Prakash C, Tiwari VK, Hussain T, 2013a. Optimization of water circulation period for the culture of goldfish with spinach in aquaponic system. J. Agric. Sci. 5:26-30.

Shete AP, Verma AK, Kohli MPS, Dash A, Tandel R, 2013b. Optimum Stocking Density for Growth of Goldfish, Carassius auratus (Linnaeus, 1758), in an Aquaponic System. Isr. J. Aquacult-Bamid. 65:1-6.

Shete AP, Verma AK, Chadha NK, Prakash C, Chandrakant MH, Nuwansi KKT, 2017. Evaluation of different hydroponic media for mint (Mentha arvensis) with common carp (Cyprinus carpio) juveniles in an aquaponic system. Aquac. Int. 25:1291-301.

Sikawa DC, Yakupitiyage A, 2010. The hydroponic production of lettuce (Lactuca sativa L) by using hybrid catfish (Clarias macrocephalus $\times$ C. gariepinus) pond water: Potentials and constraints. Agr. Water Manage. 97:1317-25.

Silva L, Gasca-Leyva E, Escalante E, Fitzsimmons KM, Lozano DV, 2015. Evaluation of biomass yield and water treatment in two aquaponic systems using the dynamic root floating technique (DRF). Sustainability 7:15384-99.

Sreejariya P, Raynaud T, Dabbadie L, Yakupitiyage A, 2016. Effect of water recirculation duration and shading on lettuce (Lactuca sativa) growth and leaf nitrate content in a commercial aquaponic system. Turk. J. Fish. Aquat. Sci. 16:311-9.

Tidwell JH, Allan G, 2012. The role of aquaculture. In: J. H. Tidwell (Ed.), Aquaculture production systems. WileyBlackwell, Oxford, UK.

Trang NTD, Schierup HH, Brix H, 2010. Leaf vegetables for use in integrated hydroponics and aquaculture systems: Effects of root flooding on growth, mineral composition and nutrient uptake. Afr. J. Biotechnol. 9:4186-96.

Turcios AE, Papenbrock J, 2014. Sustainable treatment of aquaculture effluents - what can we learn from the past for the future? Sustainability 6:836-56.

Tyson RV, Treadwell DD, Simonne EH, 2011. Opportunities and challenges to sustainability in aquaponic systems. HortTechnol. 21:6-13.

Vandam DA, Anderson TS, de Villiers D, Timmons MB, 2017. Growth and tissue elemental composition response of spinach (Spinacia oleracea) to hydroponic and aquaponic water quality conditions. Horticulturae 3:32.

Vymazal J, 2007. Removal of nutrients in various types of constructed wetlands. Sci. Total Environ. 380:48-65.

Yildiz HY, Robaina L, Pirhonen J, Mente E, Domínguez D, Parisi G, 2017. Fish welfare in aquaponic systems: its relation to water quality with an emphasis on feed and faeces - A Review. Water 9:13.

Wahyuningsih S, Effendi H, Wardiatno Y, 2015. Nitrogen removal of aquaculture wastewater in aquaponic recirculation system. AACL Bioflux 8:491-9.

Wang CY, Chang CY, Chien YH, Lai HT, 2016. The performance of coupling membrane filtration in recirculating aquaponic system for tilapia culture. Int. Biodeter. Biodegr. 107:21-30.

Wang S, Peng Y, 2010. Natural zeolites as effective adsorbents in water and wastewater treatment. Chem. Eng. J. 156:11-24.

Wießner A, Kappelmeyer U, Kuschk P, Kästner M, 2005. Influence of the redox condition dynamics on the removal efficiency of a laboratory-scale constructed wetland. Water Res. 39:248-56.

Wongkiew S, Hu Z, Chandran K, Lee JW, Khanal SK, 2017. Nitrogen transformations in aquaponic systems: A review. Aquac. Eng. 76:9-19.

Wu D, Zhang B, Li C, Zhang Z, Kong H, 2006. Simultaneous removal of ammonium and phosphate by zeolite synthesized from fly ash as influenced by salt treatment. J. Colloid Interf. Sci. 304:300-6.

Wu S, Kuschk P, Brix H, Vymazal J, Dong R, 2014. Development of constructed wetlands in performance intensifications for 
wastewater treatment: a nitrogen and organic matter targeted review. Water Res. 57:40-55.

Yen HY, Chou JH, 2016. Water purification by oyster shell biomedium in a recirculating aquaponic system. Ecol. Eng. 95:229-36.

Zou Y, Hu Z, Zhang J, Xie H, Guimbaud C, Fang Y, 2016b. Effects of $\mathrm{pH}$ on nitrogen transformations in media-based aquaponics. Bioresour. Technol. 210:81-7.
Zou Y, Hu Z, Zhang J, Xie H, Liang S, Wang J, Yan R, 2016a. Attempts to improve nitrogen utilization efficiency of aquaponics through nitrifies addition and filler gradation. Environ. Sci. Pollut. R. 23:6671-9.

Zou Y, Hu Z, Zhang J, Guimbaud C, Wang Q, Fang Y, 2016c. Effect of seasonal variation on nitrogen transformations in aquaponics of northern China. Ecol. Eng. 94:30-6. 